\title{
Value of measuring serum angiotensin I converting enzyme and serum lysozyme in the management of sarcoidosis
}

\author{
C W G TURTON,1 E GRUNDY, ${ }^{2}$ G FIRTH, ${ }^{2}$ D MITCHELL, ${ }^{1}$ B G RIGDEN, ${ }^{2}$ \\ AND M TURNER-WARWICK ${ }^{1}$
}

From the Department of Medicine (Thoracic Medicine), ${ }^{1}$ Cardiothoracic Institute, Brompton Hospital, London SW 3 6HP and Centre for Medical Research, ${ }^{2}$ University of Sussex, Falmer, Brighton, Sussex, $U K$

ABSTRACT Serum angiotensin I converting enzyme (ACE) and lysozyme have been measured in 23 controls, 115 patients with sarcoidosis, and 64 with other chest diseases. Both enzymes were significantly raised in sarcoidosis. ACE was raised above the normal range in 21 of $72(29 \%)$ patients with definite sarcoidosis and in 17 of $38(45 \%)$ of those who were untreated and seen within one year of presentation. The rise discriminated usefully between those with stable and progressive disease ( $5 \%$ and $62 \%$ respectively). Lysozyme was raised in 50 of $72(69 \%)$ patients with sarcoidosis but also in 11 of $54(20 \%)$ patients with other chest diseases. Discrimination between stable and progressive disease was useful only if very high levels were considered. Five patients had serial measurements after treatment with oral steroids and showed a progressive fall in levels of both enzymes, but patients with other diseases also showed a significant fall within the normal range when so treated. Measurement of these enzymes may help in the management of some cases of sarcoidosis, but results require critical interpretation.

Problems in managing sarcoidosis include diagnosis in atypical cases and the assessment of activity in chronic disease. Lieberman $(1975,1976)$ reported that serum angiotensin I converting enzyme (ACE) was raised in sarcoidosis, and its measurement was claimed to be useful for diagnosis and following the effects of treatment. These findings were supported by Ashutosh and Keighley (1976), Fanburg et al (1976), and Simonowitz et al (1977), but considerable overlap with normal values was found by Silverstein et al (1976), who also reported raised levels in sarcoid lymph nodes.

Serum lysozyme is also raised in sarcoidosis (Pascual et al, 1973), though it may be raised in other infections and neoplastic diseases. Its measurement has been claimed to be useful in following the activity of sarcoidosis (Selroos and Klockars, 1977). When both enzymes are measured in the same patients, positive correlation is significant in sarcoidosis but not in controls (Silverstein et al, 1977).

We have measured both enzymes in controls and patients with sarcoidosis and other chest diseases and we assess their value in managing sarcoidosis.

\section{Patients and methods}

Controls were 13 female and 10 male healthy hospital and laboratory workers aged between 22 and 64 years (mean 34).

Patients attended the Brompton Hospital or the Lewes Chest Clinic. There were 72 patients with definite sarcoidosis where the clinical diagnosis had been confirmed histologically by tissue biopsy or the Kveim test. There were 41 women and 31 men aged between 19 and 67 years (mean 37). Eleven were black and the rest white. Forty-three further patients had a confident clinical diagnosis of sarcoidosis without histological confirmation and were classified as "probable sarcoidosis." There were 21 women and 22 men aged from 21 to 71 (mean 36). Five were black, two Asian, and the rest white. These groups were considered separately. Patients were classified according to their chest radiographs as follows: 
Bilateral hilar lymphadenopathy (BHL)-Symmetrical enlargement of hilar lymph nodes, sometimes with enlargement of paratracheal nodes. Fifteen had definite sarcoidosis, and seven of these had erythema nodosum.

Pulmonary infiltration-Bilateral fine nodular mottling with or without BHL.

Pulmonary fibrosis-Distortion of lung architecture characterised either by bilateral upper lobe contraction in the absence of calcification or by widespread linear shadowing.

Extrathoracic-When there was prominent involvement of extrathoracic lymph nodes, liver, spleen, or eyes or when there was hypercalcaemia the patients were so classified in addition to their intrathoracic disease. Seventeen had definite sarcoidosis, and ten of these had no thoracic involvement.

The difficulties of determining the time of onset of sarcoidosis are recognised. The time of presentation of disease was taken as the date of first symptoms or finding of abnormal chest radiograph. The patients were divided into those with onset less than one year before assessment, who were considered to have "acute" disease, and those with disease of longer standing.

Forty-seven patients with pulmonary infiltrates or fibrosis were divided into those with stable or progressive disease by clinical, radiographic, and physiological assessment. Seventeen patients were found to have unequivocal deterioration of the chest radiograph with regard to pulmonary infiltration when the immediately previous (three to 28 months) or subsequent (one to six months) films were compared blindly with those taken at the time of assessment. Five of these had an associated fall of carbon monoxide gas transfer (TLCO) of greater than $20 \%$ predicted. These patients were considered "progressive." None of those radiographically unchanged had changes of TLCo as great as $20 \%$ predicted or had deteriorated symptomatically. These were considered "stable."

Sixty-four patients with various other diseases affecting the lungs were also investigated. They included patients with active post-primary pulmonary tuberculosis (eight), old pulmonary tuberculosis (four), cryptogenic fibrosing alveolitis (26), asthma (eight), and carcinoma of the bronchus (eight). Other diseases included Wegener's granulomatosis, eosinophilic granuloma, lymphosarcoma, and emphysema.

\section{EFFECT OF STEROID TREATMENT}

Five patients had serial measurements of both enzymes for up to 12 weeks. Nine patients with diseases other than sarcoidosis, and with normal enzyme levels initially, had second determinations up to one month after starting treatment with oral prednisone.

Venous blood was taken. Serum was separated within four hours and stored at $-20^{\circ} \mathrm{C}$.

$A C E$ was measured by the method described by Cushman and Cheung (1971) as modified by Lieberman (1975). This is based on the spectrophotometric measurements of hippuric acid released from benzoyl-glycyl-L-histidyl-L-leucine by ACE. $0.2 \mathrm{ml}$ of serum are added to $0.1 \mathrm{ml}$ of substrate solution (12.5 M hippuryl-L-histidyl-Lleucine in potassium phosphate-sodium chloride buffer at $\mathrm{pH} 8.3$ prepared one day previously) and incubated at $37^{\circ} \mathrm{C}$ for 45 minutes. The reaction is terminated by adding $0.3 \mathrm{ml}$ of $1 \mathrm{M}$ hydrochloric acid. The tubes are cooled at $4^{\circ} \mathrm{C}$ for 10 minutes. $1.5 \mathrm{ml}$ of ethyl acetate is added to each tube and vortex mixed for 15 seconds. The tubes are centrifuged at $2500 \mathrm{rpm}$ for 15 minutes at $10^{\circ} \mathrm{C} .1 .0 \mathrm{ml}$ of the upper solvent layer is pipetted into a tall tube, and heated on a hot plate at $120^{\circ} \mathrm{C}$ to dryness. After cooling, $1.0 \mathrm{ml}$ of $1 \mathrm{M}$ sodium chloride is added and vortex mixed for 15 seconds. A further $2.0 \mathrm{ml}$ of $1 \mathrm{M}$ sodium chloride is then added and mixed by inversion. The reconstituted extracts in $\mathrm{M} \mathrm{NaCl}$ show a tendency to form turbid suspensions using this method. The variability of results, which has led to the assay being performed in triplicate (Fanburg et al, 1976), may be related to this phenomenon. The problem can be overcome by passing each suspension through a $0.45 \mu \mathrm{m}$ membrane filter before spectrophotometric determination. The optical density of the extract, and of appropriate blanks, are measured at $228 \mathrm{~nm}$ using the ultraviolet lamp of a Pye Unicam SP 1800 spectrophotometer, ACE activity is defined as nanomoles of hippuric acid formed per minute under the assay conditions and expressed as units of ACE per ml serum.

Lysozyme was measured by the method of $D$ Litwack (1955) as modified by Firth (1976), where continuous rate reaction under conditions of $\bar{N}$ optimum substrate concentration, $\mathrm{pH}$, and ionic strength is measured. This is based on the spectro- $N$ photometric measurement of lysis of Micrococcus $\underset{\omega}{N}$

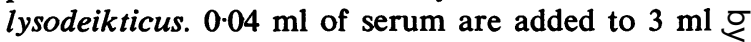
of a working substrate solution made up of $140 \mathrm{mg} 0$ of $M$ lysodeikticus per litre in a $0.04 \mathrm{M} \mathrm{pH} 6.3 \Phi$ sodium phosphate-sodium chloride-bovine albu- $\stackrel{?}{+}$ min-sodium azide buffer. Estimations were 0 carried out at $37^{\circ} \mathrm{C}$ in a Pye Unicam SP 1800 spectrophotometer. The decrease in absorbance at $\stackrel{D}{\Omega}$ $292 \mathrm{~nm}$ was followed for one minute. Standards $\AA$ were prepared from a solution of human lysozyme 0 extracted from urine of patients with monocytic 
leukaemia. Results are reported as "mg of lysozyme per litre."

Statistics-Groups were compared using the non-paired two-tailed Student's $t$ test. Paired results were compared by the paired $t$ test. Correlation coefficients were calculated using the least squares regression equation. Normal ranges were taken as the mean \pm two standard deviations of normal values. $P$ values $<0.05$ were considered significant.

\section{Results}

\section{NORMAL RANGES}

The normal range for ACE was 12-41 units and for lysozyme $0.9-2.6$ units.

\section{RESULTS IN SARCOIDOSIS}

The numbers of patients in various groups, their means, one standard deviation, significance of differences from normals, number and percentage raised above the normal range are shown for $\mathrm{ACE}$ in table 1 and for lysozyme in table 2. Serum ACE was raised significantly in the groups of patients with definite sarcoidosis who were not on steroids. The numbers of patients with raised levels were rather small-29\% of all patients with definite sarcoidosis and $45 \%$ of those untreated with steroids and seen within one year of presentation. ACE was raised in only one patient on steroids. The levels in those patients with BHL and erythema nodosum did not differ from those with BHL alone. Fewer (19\%) of those patients without histological confirmation for the diagnosis had raised levels, but the same trends with regard to the duration of disease and steroid treatment were present. The highest level of ACE recorded was 81 units, twice the upper limit of the normal range. ACE was raised in one of $19(5 \%)$ patients classified stable but in eight of $13(62 \%)$ untreated progressive patients. This is significant when compared with the whole definite sarcoidosis group $\left(\chi^{2}=7.03, \mathrm{P}<0.01\right)$.

Serum lysozyme was also raised significantly in the patients with definite sarcoidosis, and $69 \%$ had raised levels. This proportion varied little with time from presentation or in respect of steroid treatment. A similar proportion of those patients without histological support for the diagnosis had raised levels. Although the 13 untreated progressive patients all had raised levels, so did 11 of 19 $(58 \%)$ untreated stable patients. If very high levels (greater than six SDs above the normal mean, 4.4 units) are considered, however, there were nine $(69 \%)$ in the progressive group and three $(16 \%)$ in the stable group. The highest level of lysozyme recorded was $12 \cdot 8$ units, about five times greater than the upper limit of normal.

\section{RESULTS IN OTHER DISEASES}

ACE was raised in two of $64(4 \%)$ patients with chest diseases other than sarcoidosis. One of these had siderosilicosis and the other fibrosing alveolitis with progressive systemic sclerosis. Lysozyme was raised in 11 of $54(20 \%)$ patients with other diseases. Serum ACE was significantly higher in those of the miscellaneous group as a whole who were untreated compared with those on steroids

Table 1 Serum ACE in sarcoidosis and other chest diseases

\begin{tabular}{|c|c|c|c|c|c|c|}
\hline \multirow[t]{2}{*}{ Group } & \multirow[t]{2}{*}{ Number } & \multirow[t]{2}{*}{ Mean } & \multirow[t]{2}{*}{$I S D$} & \multirow[t]{2}{*}{$\mathbf{P}$} & \multicolumn{2}{|c|}{ Raised } \\
\hline & & & & & $(n)$ & $(\%)$ \\
\hline Controls & 23 & $26 \cdot 6$ & $7 \cdot 3$ & - & 1 & 4 \\
\hline $\begin{array}{l}\text { Definite sarcoidosis } \\
\text { Recent onset, untreated } \\
\text { BHL only } \\
\text { Mottling } \\
\text { Extrathoracic } \\
\text { Onset }>1 \text { year, untreated } \\
\text { Mottling } \\
\text { Fibrosis } \\
\text { Extrathoracic } \\
\text { Steroid treated }\end{array}$ & $\begin{array}{r}72 \\
38 \\
15 \\
15 \\
12 \\
21 \\
8 \\
10 \\
5 \\
13\end{array}$ & $\begin{array}{l}35 \cdot 6 \\
39 \cdot 5 \\
39 \cdot 3 \\
38 \cdot 3 \\
50 \cdot 1 \\
34 \cdot 3 \\
31 \cdot 5 \\
41 \cdot 3 \\
33 \cdot 4 \\
27 \cdot 1\end{array}$ & $\begin{array}{r}14 \cdot 4 \\
14 \cdot 3 \\
9 \cdot 7 \\
18 \cdot 1 \\
17 \cdot 1 \\
15 \cdot 3 \\
10 \cdot 2 \\
16 \cdot 8 \\
21 \cdot 9 \\
9 \cdot 3\end{array}$ & $\begin{array}{l}<0.001 \\
<0.001 \\
<0.001 \\
<0.01 \\
<0.001 \\
<0.05 \\
\text { NS } \\
<0.001 \\
\text { NS } \\
\text { NS }\end{array}$ & $\begin{array}{r}21 \\
17 \\
7 \\
6 \\
8 \\
3 \\
1 \\
2 \\
2 \\
1\end{array}$ & $\begin{array}{r}29 \\
45 \\
47 \\
40 \\
67 \\
14 \\
13 \\
20 \\
40 \\
8\end{array}$ \\
\hline Probable sarcoidosis & 43 & $32 \cdot 7$ & $12 \cdot 8$ & $<0.05$ & 8 & 19 \\
\hline $\begin{array}{l}\text { Sarcoidosis } \\
\text { Stable, untreated } \\
\text { Stable, steroid treated } \\
\text { Progressive, untreated } \\
\text { Progressive, steroid treated }\end{array}$ & $\begin{array}{r}19 \\
11 \\
13 \\
4\end{array}$ & $\begin{array}{l}30 \cdot 2 \\
33 \cdot 2 \\
48 \cdot 2 \\
24 \cdot 6\end{array}$ & $\begin{array}{l}10 \cdot 9 \\
13 \cdot 0 \\
15 \cdot 3 \\
10 \cdot 6\end{array}$ & $\begin{array}{l}\text { NS } \\
\text { NS } \\
<0.001 \\
\text { NS }\end{array}$ & $\begin{array}{l}1 \\
1 \\
8 \\
0\end{array}$ & $\begin{array}{r}5 \\
9 \\
62 \\
0\end{array}$ \\
\hline $\begin{array}{l}\text { Miscellaneous lung diseases } \\
\text { Untreated with steroids } \\
\text { On steroids }\end{array}$ & $\begin{array}{l}64 \\
44 \\
20\end{array}$ & $\begin{array}{l}23 \cdot 6 \\
26 \cdot 1 \\
19 \cdot 0\end{array}$ & $\begin{array}{l}9 \cdot 2 \\
9 \cdot 4 \\
7 \cdot 1\end{array}$ & $\begin{array}{l}\text { NS } \\
\text { NS } \\
\text { NS }\end{array}$ & $\begin{array}{l}2 \\
2 \\
0\end{array}$ & $\begin{array}{l}4 \\
5 \\
0\end{array}$ \\
\hline
\end{tabular}


Table 2 Serum lysozyme in sarcoidosis and other chest diseases

\begin{tabular}{|c|c|c|c|c|c|c|}
\hline \multirow[t]{2}{*}{ Group } & \multirow[t]{2}{*}{ Number } & \multirow[t]{2}{*}{ Mean } & \multirow[t]{2}{*}{$1 S D$} & \multirow[t]{2}{*}{$\mathbf{P}$} & \multicolumn{2}{|c|}{ Raised } \\
\hline & & & & & $(n)$ & $(\%)$ \\
\hline Controls & 23 & $1 \cdot 76$ & 0.42 & - & 0 & 0 \\
\hline $\begin{array}{l}\text { Definite sarcoidosis } \\
\text { Recent onset, untreated } \\
\text { BHL only } \\
\text { Mottling } \\
\text { Extrathoracic } \\
\text { Onset }>1 \text { year, untreated } \\
\text { Mottling } \\
\text { Fibrosis } \\
\text { Extrathoracic } \\
\text { Steroid treated }\end{array}$ & $\begin{array}{r}72 \\
38 \\
15 \\
15 \\
12 \\
21 \\
8 \\
10 \\
5 \\
13\end{array}$ & $\begin{array}{l}3 \cdot 9 \\
4 \cdot 4 \\
3 \cdot 6 \\
4 \cdot 8 \\
5 \cdot 4 \\
3 \cdot 5 \\
3 \cdot 1 \\
3 \cdot 8 \\
3 \cdot 7 \\
3 \cdot 3\end{array}$ & $\begin{array}{l}2 \cdot 2 \\
2 \cdot 6 \\
1 \cdot 6 \\
2 \cdot 5 \\
3 \cdot 6 \\
1 \cdot 3 \\
0 \cdot 8 \\
1 \cdot 6 \\
0.9 \\
1 \cdot 8\end{array}$ & $\begin{array}{l}<0.001 \\
<0.001 \\
<0.001 \\
<0.001 \\
<0.001 \\
<0.001 \\
<0.001 \\
<0.001 \\
<0.001 \\
<0.001\end{array}$ & $\begin{array}{r}50 \\
29 \\
10 \\
13 \\
10 \\
14 \\
5 \\
7 \\
4 \\
7\end{array}$ & $\begin{array}{l}69 \\
76 \\
67 \\
87 \\
83 \\
67 \\
63 \\
70 \\
80 \\
54\end{array}$ \\
\hline Probable sarcoidosis & 43 & $3 \cdot 7$ & $2 \cdot 2$ & $<0.001$ & 29 & 67 \\
\hline $\begin{array}{l}\text { Sarcoidosis } \\
\text { Stable, untreated } \\
\text { Stable, steroid treated } \\
\text { Progressive, untreated } \\
\text { Progressive, steroid treated }\end{array}$ & $\begin{array}{r}19 \\
11 \\
13 \\
4\end{array}$ & $\begin{array}{l}3 \cdot 3 \\
2 \cdot 9 \\
6 \cdot 1 \\
4 \cdot 5\end{array}$ & $\begin{array}{l}1 \cdot 4 \\
1 \cdot 1 \\
2 \cdot 6 \\
2 \cdot 9\end{array}$ & $\begin{array}{l}<0.001 \\
<0.001 \\
<0.001 \\
<0.001\end{array}$ & $\begin{array}{r}11 \\
6 \\
13 \\
3\end{array}$ & $\begin{array}{r}58 \\
55 \\
100 \\
75\end{array}$ \\
\hline $\begin{array}{l}\text { Miscellaneous lung diseases } \\
\text { Untreated with steroids } \\
\text { On steroids }\end{array}$ & $\begin{array}{l}54 \\
34 \\
20\end{array}$ & $\begin{array}{l}2 \cdot 2 \\
2 \cdot 2 \\
2 \cdot 2\end{array}$ & $\begin{array}{l}0.9 \\
1.6 \\
1 \cdot 1\end{array}$ & $\begin{array}{l}\text { NS } \\
\text { NS } \\
\text { NS }\end{array}$ & $\begin{array}{r}11 \\
8 \\
3\end{array}$ & $\begin{array}{r}20 \\
24 \\
9\end{array}$ \\
\hline
\end{tabular}

Table $3 A C E$ and lysozyme in various chest diseases

\begin{tabular}{|c|c|c|c|c|c|c|c|c|c|}
\hline \multirow[t]{3}{*}{ Group } & \multirow[t]{3}{*}{ Number } & \multicolumn{4}{|l|}{$A C E$} & \multicolumn{4}{|c|}{ Lysozyme } \\
\hline & & \multirow[t]{2}{*}{ Mean } & \multirow[t]{2}{*}{$I S D$} & \multicolumn{2}{|c|}{ Raised } & \multirow[t]{2}{*}{ Mean } & \multirow[t]{2}{*}{$I S D$} & \multicolumn{2}{|c|}{ Raised } \\
\hline & & & & $(n)$ & $(\%)$ & & & $(n)$ & $(\%)$ \\
\hline Pulmonary tuberculosis - active & 8 & $20 \cdot 8$ & $11 \cdot 0$ & 0 & 0 & $2 \cdot 3$ & $1 \cdot 2$ & 2 & 25 \\
\hline Pulmonary tuberculosis-old & 4 & $26 \cdot 9$ & $7 \cdot 4$ & 0 & 0 & $1 \cdot 8$ & $0 \cdot 31$ & 0 & 0 \\
\hline Cryptogenic fibrosing alveolitis - untreated & 16 & $24 \cdot 4$ & $9 \cdot 4$ & 1 & 6 & $2 \cdot 2$ & 0.73 & 5 & 31 \\
\hline Cryptogenic fibrosing alveolitis-steroids & 10 & $16 \cdot 4$ & $7 \cdot 6$ & 0 & 0 & $2 \cdot 5$ & 1.5 & 3 & 30 \\
\hline Asthma (atopic) untreated & 6 & $25 \cdot 1$ & $5 \cdot 8$ & $\mathbf{0}$ & 0 & $2 \cdot 1$ & 0.80 & 0 & $\mathbf{0}$ \\
\hline Asthma-on steroids & 6 & $23 \cdot 8$ & 3.6 & 0 & $\mathbf{0}$ & $2 \cdot 0$ & 0.75 & 0 & 0 \\
\hline Carcinoma of the bronchus & 8 & $31 \cdot 6$ & $4 \cdot 2$ & $\mathbf{0}$ & $\mathbf{0}$ & $2 \cdot 1$ & 0.94 & 1 & 13 \\
\hline Wegener's granuloma & 3 & $17 \cdot 1$ & $7 \cdot \overline{5}$ & 0 & $\mathbf{0}$ & $2 \cdot 0$ & $1 \cdot 7$ & 0 & 0 \\
\hline Eosinophilic granuloma & 2 & $22 \cdot 5$ & $6 \cdot 3$ & 0 & 0 & $2 \cdot 3$ & 0.35 & 0 & 0 \\
\hline
\end{tabular}

$(P<0.01)$. Details of the results in the other diseases are shown in table 3.

\section{EFFECT OF STEROID TREATMENT}

The results of serial measurement of both enzymes in patients with sarcoidosis are shown in fig 1 . Levels fell rapidly towards normal within a few weeks. When it became apparent that steroid treatment was associated with lower levels even in diseases where the enzymes were not raised, it seemed possible that steroids might have an independent effect. Figure 2 shows paired results before and after treatment with oral steroids in patients without sarcoidosis. There is a $28 \%$ fall in ACE, paired $t$ test $\mathrm{P}<0.001$, non-paired $t$ test $\mathrm{P}<0.01$, and a $24 \%$ fall in lysozyme, paired $t$ test $\mathrm{P}<0.01$, non-paired $t$ test $\mathrm{P}<0.05$.

\section{COMPARISON OF ACE AND LYSOZYME}

There was no significant correlation between ACE and lysozyme in controls $(r=0 \cdot 17)$ but in patients with definite sarcoidosis there was a significant positive correlation $(r=0.567, \mathrm{P}<0.001)$. ACE was raised in two patients with definite sarcoidosis when lysozyme was normal. Lysozyme was raised in 31 patients when ACE was normal, and five of these were in the very high range.

\section{Discussion}

The ACE levels in normal controls are comparable to those reported by Fanburg et al (1976) and Silverstein et al (1976). The lower levels reported by Lieberman (1975), and Ashutosh and Keighley (1976), are due to an error in calculation that has been acknowledged by Lieberman (1976). Varying levels of lysozyme have been reported in normal controls because of the use of different standards. We confirm previous reports (Lieberman, 1975, 1976; Ashutosh and Keighley, 1976; Fanburg et 

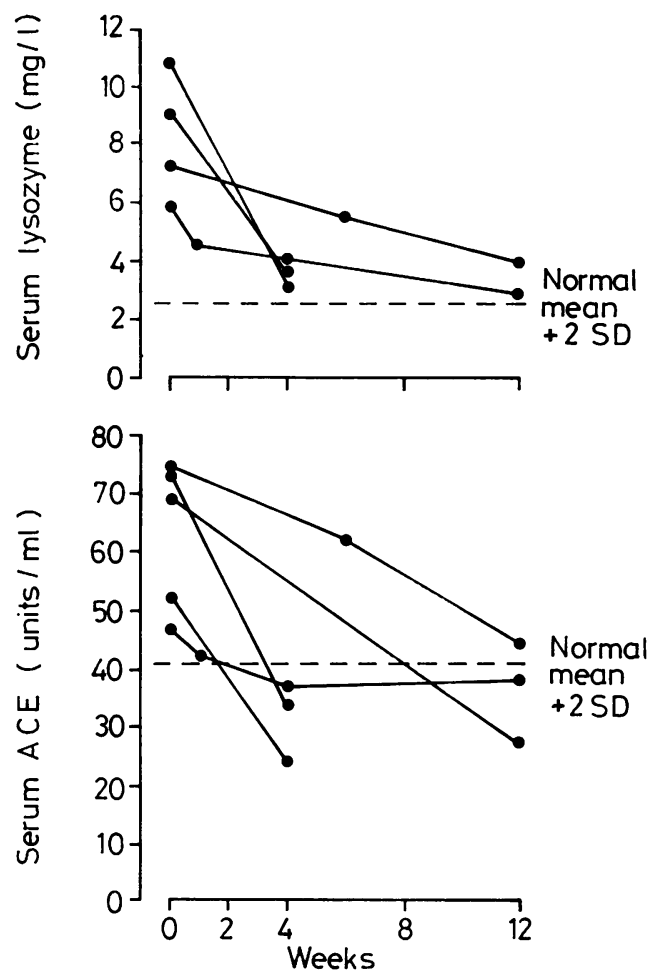

Fig 1 Results of serum $A C E$ (units $/ m l$ ) and lysozyme $(\mathrm{mg} / \mathrm{l})$ in patients with sarcoidosis after treatment with oral steroids from zero time. Horizontal dotted line represents upper limit of normal range.

al, 1976; Silverstein et al, 1976; Simonowitz et al, 1977) that serum ACE is raised in patients with sarcoidosis, particularly within one year of presentation. The investigation is less than ideal as a diagnostic test because, although there are very few positives in other diseases, the negative rate for all patients with definite sarcoidosis is over $70 \%$, and the range of abnormality narrow. The rise of ACE does discriminate usefully between those classified by other criteria as having stable or progressive disease.

Serum lysozyme is also significantly raised in sarcoidosis, and the numbers with raised levels are greater than for ACE. The investigation is of little value diagnostically because of the numbers of positives in other diseases. It does not discriminate between stable and progressive disease, but the range of abnormality is greater than for $\mathrm{ACE}$, and consideration of very high levels improves discrimination.

The suggestion that measurement of these enzymes is useful in following the effects of treat-
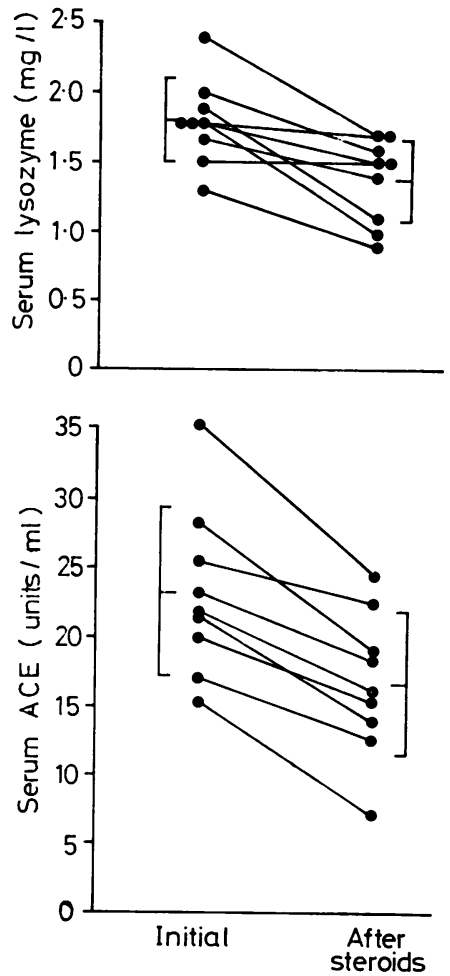

Fig 2 Results of serum ACE (units/ml) and lysozyme ( $m g / l)$ in patients with diseases other than sarcoidosis after treatment with oral steroids. Bars represent means $\pm 1 S D$.

ment was based on the observation that levels were lower in patients with longstanding disease or on steroids (Lieberman, 1975; Ashutosh and Keighley, 1976; and Simonowitz et al, 1977) and the demonstration of a progressive fall within patients when started on steroids (Lieberman, 1976). The assumption was that steroids have no direct effect. We have shown that levels of both enzymes fall significantly in patients with diseases in which the enzymes are not raised and with normal initial levels, suggesting that steroids do have a direct effect independent of any action on sarcoidosis. These influences cannot be distinguished, which complicates interpretation of serial measurements when treatment has been started or changed.

It is concluded that the rise of serum ACE or considerable rise of lysozyme does represent active sarcoidosis, though this is not excluded by normal levels. It should be emphasised that the disease is usually self-limiting and that demonstration of active disease does not necessarily indicate the 
need for treatment. It would, however, be reasonable to follow such patients carefully. These enzymes sometimes give complementary information and their measurement may help in managing difficult cases, but for the reasons discussed the results need critical interpretation.

We thank the physicians of the Brompton Hospital for referring patients.

\section{References}

Ashutosh, K, and Keighley, J F H (1976). Diagnostic value of serum angiotensin converting enzyme activity in lung disease. Thorax, 31, 552-557.

Cushman, D W, and Cheung, H S (1971). Spectrophotometric assay and properties of the angiotensin converting enzyme of rabbit lung. Biochemical Pharmacology, 20, 1637-1648.

Fanburg, B L, Schoenberger, M D, Bachus, B, and Snider, G L (1976). Elevated serum angiotensin I converting enzyme in sarcoidosis. American Review of Respiratory Disease, 114, 525-528.

Firth, G (1976). Lysozyme. MSc Thesis, University of Surrey.

Lieberman, J (1975). Elevation of serum angiotensin I converting enzyme (ACE) level in sarcoidosis. American Journal of Medicine, 59, 365-372.

Lieberman, J (1976). The specificity and nature of serum-angiotensin-converting enzyme elevations in sarcoidosis. Annals of the New York Academy of Science, 278, 488-497.
Litwack, G (1955). Photometric determination of lysozyme activity. Proceedings of the Society for Experimental Biology (New York), 89, 401-403.

Pascual, R S, Gee, J B L, and Finch, S C (1973). Usefulness of serum lysozyme measurement in diagnosis and evaluation of sarcoidosis. New England Journal of Medicine, 289, 1074-1076.

Selroos, O, and Klockars, M (1977). Serum lysozyme in sarcoidosis. Scandanavian Journal of Respiratory Disease, 58, 110-116.

Silverstein, E, Friedland, J, Lyons, H A, and Gourin, A (1976). Evaluation of angiotensin-converting enzyme in granulomatous lymph nodes and serum in sarcoidosis: clinical and possible significance. Annals of the New York Academy of Science, 278, 498-513.

Silverstein, E, Friedland, J, and Ackerman, T (1977). Elevation of granulomatous lymph node and serum lysozyme in sarcoidosis and correlation with angiotensin converting enzyme. American Journal of Clinical Pathology, 68, 219-224.

Simonowitz, L J, Solliday, N, Celic, L, and Cugell, D (1977). Serial measurement of antinogensin converting enzyme and diffusing capacity in sarcoidosis. American Review of Respiratory Disease, 115, (abstr) 164.

Requests for reprints to: Dr C W G Turton, Department of Medicine (Thoracic Medicine), Cardiothoracic Institute, Brompton Hospital, Fulham Road, London SW3 6HP. 